\title{
Predictors for Early Fontan Failure: Findings from the 8-Year Fontan Operation at a Single Institution
}

\author{
Dai Tran ${ }^{1}$, Thanh $\mathrm{Le}^{1}$, Van Dang ${ }^{2}$, and Hoang-Long $\mathrm{Vo}^{2}$ \\ ${ }^{1}$ E Hospital \\ ${ }^{2}$ Hanoi Medical University
}

June 25, 2020

\begin{abstract}
Although early postoperative outcomes after Fontan improved in the modern era, the convincing evidence in the resource-scare setting was sparse. Our study aimed to determine the incidence of early Fontan failure (EFF) in a contemporary series of palliated patients and to identify its potential risk factors. A single-center retrospective study was conducted between 2012 and 2019 on 145 patients undergoing the Fontan procedure. The primary outcome of interest was EFF, defined as death, Fontan takedown, or listing for heart transplantation prior to hospital discharge or within 30 postoperative days. Our study reported the incidence of EFF of $9.66 \%$ ( $\mathrm{n}=14$ : thirteen deaths, and one Fontan takedown). In the univariate analysis for pre-operative data, the anatomical diagnosis of unbalanced atrioventricular (AV) septal defect, situs inversus form, AV valve regurgitation, large aorta-pulmonary circulation in Doppler echocardiography, elevated pulmonary artery pressure (PAP), and elevated pulmonary vascular resistance were significantly associated with EFF. At the Fontan, four risk factors influencing EFF included pulmonary artery reconstruction, AV valve repair, bleeding, and elevated PAP. Post-operative edema was also significantly associated with EFF. A final reduced model with multivariate logistic regression analysis indicated preoperative elevated PAP, AV valve repair at Fontan, and postoperative elevated PAP were independent predictors for EFF. In conclusion, EFF is relatively high in our series, and is associated with significant mortality. Patients with a single ventricle physiology undergoing preoperative elevated PAP, AV valve repair at Fontan, and postoperative elevated PAP were identified as independent risk factors to predict EFF.
\end{abstract}

\section{Introduction}

Early Fontan failure (EFF) has been used to define the postoperative state of low systemic perfusion, high Fontan circuit pressures and large volume requirements, which is unresponsive to inotropes and is the major cause of early death following completion of Fontan. In case series belonging to the early era of the Fontan procedure, reported EFF rates were over 10\%, with consequent early mortality rates of 9-15\% [1-4]. There were several suggested strategies to avoid EFF of a careful collection of cases, avoiding Fontan completion in those at high risk for EFF [5], usage of Fontan takedown to circulate intermediately [2-18] and extracorporeal membrane oxygenation (ECMO) as a bridge to recovery or takedown [8, 9, 12, 14, 19-21]. Besides early series in the literature reported mortality rates of over $85 \%$, meaning the survival rates following EFF were usually low [1-4], however, survival estimates were reached with the use of ECMO and/or takedown in the more recent series of $33-66 \%[8-11,15,19,20]$.

Improved understanding, practice, and strategies seem to have neutralized some of the known risk factors. Commonly considered risk factors for EFF reported to be heterotaxy syndrome [4, 6, 12], right ventricular morphology $[12,16]$, common atrioventricular $(\mathrm{AV})$ valve $[4,15,22]$, elevated preoperative pulmonary artery pressure (PAP) [2-5, 14, 15, 22], increased preoperative ventricular end-diastolic pressure (VEDP) [1, 3], use of extracardiac conduit $[6,8]$, elevated postoperative circuit pressures $[1,3,4]$, prolonged cardiopulmonary bypass time $[12,13,22]$, and prolonged cross-clamp time $[3,8,13]$. Yet the convincing evidence of early postoperative outcomes after Fontan in the resource-scare setting was sparse; therefore, the first time in 
Vietnam we conducted this study with the aims of determining the incidence of EFF in the patients with single-ventricle lesions receiving an extracardiac Fontan operation and identifying the potential risk factors for $\mathrm{EFF}$ in these patients.

\section{Methods}

\section{Study Patients}

We retrospectively analyzed a total of 145 consecutive patients with diagnosis of single ventricle physiology who were admitted and underwent Fontan procedure in the Cardiovascular Center of E Hospital (Hanoi, Vietnam) from August 2012 through December 2019. Table 1 provided the criteria for selecting a given patient for Fontan surgery in our center. The patients and their families who did not agree to participate were excluded from this study.

\section{Study Outcome}

The primary outcome of interest was early Fontan failure, defined as death, Fontan takedown, or listing for heart transplantation prior to hospital discharge or within 30 postoperative days.

All potential predictive factors have been used on the basis of clinical assessment, literature analysis and availability of our hospital.

\section{Surgical Techniques}

Stage I operations included Glenn procedure, shunt-type operations, pulmonary arterial banding, pulmonary artery reconstruction, and Damus-Kaye-Stansel (DKS) procedure. For stage II, bidirectional cavopulmonary shunt (BCPS) was performed in all patients. Cardiac catheterization was performed before BCPS in a patient number out of 145 patients because several those did not have enough data. Thus, all of pre-BCPS cardiac catheterization data were not adequately included in our analysis because of incomplete data. PreFontan cardiac catheterization was routinely performed for all candidates for the Fontan operation. In stage III (Fontan operation), the following concomitant surgeries were performed: the utilization of fenestration $(\mathrm{n}=145,100 \%)$, pulmonary artery reconstruction $(\mathrm{n}=15,10.34 \%)$, atrial septostomy procedure $(\mathrm{n}=16$, $11.03 \%)$, DKS procedure $(\mathrm{n}=4,2.76 \%), \mathrm{AV}$ valve repair $(\mathrm{n}=4,2.76 \%), \mathrm{AV}$ valve replacement $(\mathrm{n}=1,0.69 \%)$, manipulate aortopulmonary collateral arteries (APCA) by dissection $(\mathrm{n}=1,0.69 \%)$, and ligation APCA $(\mathrm{n}=1,0.69 \%)$. Postoperatively, we conducted early extubation and fuid restriction; supplemental oxygen by nasal cannula and medication were provided as indicated. All patients received aspirin (3-5mg $/ \mathrm{kg} /$ day) for anticoagulation when switching from heparin. Chest tubes were removed when drainage decreased to 2 $\mathrm{ml} / \mathrm{kg} /$ day.

\section{Statistical Analysis}

All analyses were performed using Stata@ 15 (StataCorp LLC, USA) for Windows. Continuous variables were expressed as mean, standard deviation (SD) with interquartile ranges (IQR). Categorical variables were presented as counts with percentage. The univariable analysis using logistic regression was used to identify risk factors (preoperative, operative and postoperative variables) for EFF in the entire cohort of patients. A total of 22 valid variables at pre-Fotan, Fontan and post-Fontan that were considered as independent variables that were put into a full model with multivariate logistic regression analysis. A stepwise backward selection strategy with $p$-values $<0.2$ was applied, and then a reduced model with multivariable logistic regression was established for final results. A $p$-value $<0.05$ was considered to be statistically significant.

\section{Ethical Approval}

All procedures conducted in studies involving human subjects were in compliance with the ethical principles of the Institutional and/or National Study Committee and the Helsinki Declaration of 1964 and its corresponding amendments or equivalent ethical standards. This study was approved by the Ethics Board of the Hanoi Medical University. All individual participants included in the study have obtained informed consent.

\section{Results}


The outcomes for patients who experienced EFF are summarized in Table 2. EFF occurred in 14 patients (9.66\%). Out of 14 patients with EFF, 13 patients died (92.86\%). Compared to the entire cohort, the overall mortality was $8.97 \%$. One patient had Fontan takedown to superior cavopulmonary connection (SCPC) that no need for ECMO support. Among the patient who had Fontan takedown, the interval from Fontan procedure to takedown was 2 days. EFF occurred in this patient having Fontan takedown resulting from hemodynamic disorders not responding to treatment. $57.14 \%$ patients with EFF (8 of 14) were directed to only one cause, while the remaining EFF was diagnosed with two causes. $57.14 \%$ of the EFF patients ( 8 of 14) were caused by the hemodynamic disorders not responding to treatment, when this figure for the multiorgan dysfunction syndrome was observed in $50 \%$ patients $(7 / 14) .14 .29 \%$ (2 of 14) was due to the bacterial sepsis or septic shock, and also, there were two EFF patients diagnosed with the cardiac arrest due to arrhythmias. We found that a patient with EFF had cerebral infarction.

Pre-fontan covariates for the entire cohort of patients who experienced EFF and those who did not experience EFF are compared in Table 3. Pre-operatively, the anatomical diagnosis of unbalanced AV septal defect (OR: $5.39,95 \%$ CI: $1.66-17.55, \mathrm{p}=0.005)$, situs inversus form (OR: 3.68, 95\%CI: $1.07-12.58, \mathrm{p}=0.038$ ), AV valve regurgitation (OR: 4.63, 95\%CI: $1.45-14.85, \mathrm{p}=0.01$ ), large aorta-pulmonary circulation in Doppler echocardiography (OR: 6.72, 95\%CI: $1.89-23.92, \mathrm{p}=0.003$ ), elevated PAP in cardiac catheterization (OR: 1.40, 95\% CI: $1.08-1.82, \mathrm{p}=0.011$ ), and elevated Rp in cardiac catheterization (OR: 6.73, 95\%CI: $1.65-$ 27.39, $\mathrm{p}=0.008$ ) were associated with $\mathrm{EFF}$ in the univariate analysis with logistic regression.

Operative and postoperative covariates for the entire cohort of patients who experienced EFF and those who did not experience EFF are compared in Table 4. In univariate analysis with logistic regression, at Fontan, four risk factors influencing EFF included pulmonary artery reconstruction (OR: 4.36, 95\%CI: 1.17 - 16.23, $\mathrm{p}=0.028$ ), AV valve repair (OR: $35.45,95 \%$ CI: $3.40-370.04, \mathrm{p}=0.003$ ), bleeding (OR: $17.07,95 \% \mathrm{CI}: 3.35-$ 87.06, $\mathrm{p}=0.001$ ), and elevated PAP (OR: 1.23, 95\%CI: $1.07-1.48, \mathrm{p}=0.005)$. Post-operative edema was also significantly associated with EFF (OR: 10.08, 95\%CI: $2.33-43.58, \mathrm{p}=0.002$ ).

A total of 22 independent variables (including preoperative, operative and postoperative data) were put into a model with multivariate logistic regression analysis. A final reduced model following utilizing a stepwise backward selection strategy with $p$-values $<0.2$ is presented in Table 5 . Preoperative increased PAP (OR: 1.84, 95\%CI: $1.12-3.00, \mathrm{p}=0.016$ ), AV valve repair at Fontan (OR: 65.85, 95\%CI: 1.95-2228.14, $\mathrm{p}=0.020$ ), and postoperative increased PAP (OR: $1.66,95 \% \mathrm{CI}: 1.19-2.33, \mathrm{p}=0.004)$ were independent predictors for EFF.

\section{Discussion}

Early postoperative outcomes after Fontan have improved in the modern era, yet the no evidence of the incidence of EFF (death, Fontan takedown, or listing for heart transplantation before discharge) in Southeast Asia has been recently reported. This study reports the preoperative characteristics, operative course and mid-term outcomes of a large contemporary series of single-ventricle patients having relatively standardized, staged palliation in a large volume centre and focuses on the incidence, and risk factors of EFF. The incidence of EFF in our case series was $9.66 \%$. Compared to case series in the early era of the Fontan procedure, our incidence of EFF was consistent when previous EFF rates of over 10\%, with consequent early mortality rates of $9-15 \%$ [1], [2], [3], [4]. However, the incidence of EFF in our study was higher when compared with other recent series [23], [24]. There are two groups of causes that are subjective and objective that the authors would like to mention to explain for this relatively high incidence. Towards subjective reasons, this is the first period in our institution that the physicians have approached procedures for single-ventricle lesions, hence, initially, actual resuscitation experience with such patients is not much. For objective reasons, resource-scare setting in our institution should be acknowledged when the equipment in the postoperative resuscitation still has several shortcomings. Typically, because our patients were not monitored to treat early soon after birth, two pre-Fontan staged single ventricle palliative surgeries were late for pulmonary vascular system and systemic ventricular function, with the pre-Fontan stage management being not delicate enough. Out of 14 patients with EFF in this study, 13 patients died (92.86\%). Compared to the entire cohort, the overall mortality was $8.97 \%$. One patient had Fontan takedown to SCPC that no need for ECMO support. Among 
the patient who had Fontan takedown, the interval from Fontan procedure to takedown was 2 days.

EFF is often reported as a primary outcome in a series of palliated single-ventricle patients, but definitions differ amongst reports, with some omitting patients having ECMO [6] and some including patients who had prolonged inotropes or ventilation [12]. Survival rates of patients who experience EFF vary widely as seen in Table 6.

In this study, we found unbalanced AV septal defect to be predictive of EFF. Most are left ventricular atrophy, the main is the right ventricle morphology, often with AV valve openings. Therefore, in this case the systemic ventricular function is often poor. To date, AV valve regurgitation is known to adversely affect outcomes in patients with Fontan circulation [25], [26]. Previous studies have highlighted variable such as AV valve regurgitation as a predictor of poor outcomes for patients undergoing single ventricle palliation [27], [26]. AV valve regurgitation was the known factor that impaired systemic ventricular function very severely for a long time before the Fontan procedure. In univariate analysis with logistic regression, we found that AV valve regurgitation was an increased risk factor for EFF in patients following Fontan procedure. We would like to highlight that, large aorta-pulmonary circulation observed in the Doppler echocardiography was big or tufts, which affected resistance and flow of pulmonary artery. This might be suitable explanation for the association amongst large aorta-pulmonary circulation and EFF in current series.

Despite the changes in surgical strategy, relatively high PAP and pulmonary vascular resistance may still be risk factors of early and late mortality of Fontan operations. There are several reports suggesting that a mean pulmonary arterial pressure $>15-18 \mathrm{~mm} \mathrm{Hg}$ and pulmonary vascular resistance $>2-4$ wood $/ \mathrm{m}^{2}$ were associated with increased mortality [28], [29]. Amelioration of these factors may optimize postoperative management. We did evaluated PAP and pulmonary vascular resistance as continuous predictor variables by means of logistic regression analysis to identify the association with EFF following Fontan procedure. The patients who had a preoperative cardiac catheterization found that higher mean PAP, a potential target for pharmacologic intervention, was an independent predictor for EFF. Our finding was consistent with a number of previous studies once showing increased preoperative PAP been described as risk factors for EFF [5], [14], [15], [17]. High pulmonary arterial pressure in single ventricular physiology can be caused by vascular hypertone, micro-thromboembolism, and/ or retrograde high pressure from increased left atrial pressure. Kaza et al. [30] and Ridderbos et al. [31] showed that intimal thickness of the small pulmonary artery was increased over time after the Fontan operation. Alson in this study, postoperative high PAP was known as one of the predictors towards EFF in the final reduced model following multivariate logistic regression analysis. Pulmonary vascular resistance was recorded in 64 patients, which was calculated from the mean pulmonary artery pressure, the pulmonary venous atrial pressure, and pulmonary blood flow. Higher preoperative pulmonary vascular resistance was seen as a risk factor for EFF, which was consistent with a previous report of Gentles TL et al [4].

Several operative variables at Fontan were also known as increased risk factors for EFF in this study, including pulmonary artery reconstruction, repair of AV valve, increased operative PAP, and bleeding during surgery. Pulmonary artery reconstruction was a difficult procedure, especially for those located near or deep in the hilum of the lung, usually the reconstruction outcomes are not satisfactory. This was also a major obstacle for the postoperative patient outcome. In current series, there were 4 patients who need to repair AV valve at Fontan. AV valve in the single-ventricle lesions is usually one AV valve loop, so the repairment ability is very difficult. If the AV valve regurgitation is completely repaired, it usually occurs after a repair. AV valve failure (moderate or greater regurgitation, or valve operation) is a risk factor for adverse outcomes in patients undergoing Fontan palliation [32]. An increasing number of patients with Fontan circulation were surviving well into adulthood [33]. AV valve regurgitation was known to adversely affect outcomes in the patients with Fontan circulation [25], [26]. The rate at which AV valve regurgitation occurs in patients undergoing Fontan palliation is not clearly elucidated, nor are the factors that predict which patients will experience $\mathrm{AV}$ valve regurgitation or require intervention. Although the patients diagnosed with moderate AV valve regurgitation was higher EFF risk compared to those with mild regurgitation, the impact of moderate to severe regurgitation on long-term outcomes has not been quantified. From the gained results in multivariate 
analysis, we found that AV valve repair was independently associated with an increased probability of EFF.

In terms of resuscitation for these patients right after surgery, postoperative edema, was reported as to be facial and / or systemic edema, was often accompanied by severe clinical symptoms. The reason for this may be due to increased pressure in the vein system. Our result showed that edema edema immediately after surgery increased the incidence of EFF.

To identify the independent predictors for EFF following Fontan procedure in this retrospective series, we performed a model with multivariate logistic regression analysis with a total of 22 independent variables including preoperative, operative and postoperative data. We found that there were three independent predictors towards EFF including preoperative increased PAP, the AV valve repair at Fontan, and postoperative increased PAP. It's difficult for the authors to compare the current regression model with previous studies because multivariate testing was not performed for EFF in several recent studies [23], [24]. The inconsistency amongst studies in the selection of possible study variables was based on clinical judgment, literature review and availability in different institutions, as well as the number of outcomes were small, so those studies only examined associations with EFF with univariable logistic regression.

The Vietnamese authors, firstly, reported a large retrospective cohort of consecutive patients with singleventricle lesions that underwent an extracardiac Fontan operation at a major academic medical institution. Therefore, this study should be viewed in light of its main limitations. First, we acknowledge this study's retrospective nature and being a single center study. Second, although a large number of variables were put into the multivariate model to control for the confounders, certain unknown heterogeneities could exist. Third, maybe the study had relatively small sample size of patients and some parameters still could not be adequately measured, hence, the final predictor model did miss other important variables, such as the complexity of the surgery process, or some cardiac catheterization data. Fourth, although all patients received a standardized management strategy from one center by a small group of surgeons, this study did not represent those of other centers.

\section{Conclusions}

We found that, the incidence of EFF was relatively high in this study, and was associated with significant mortality. Our evidence suggests that preoperative elevated PAP, AV valve repair at Fontan, and postoperative elevated PAP can reliably predict the EFF in the current era. Particularly, in the context of a developing country with resource-scare condition, a comprehensive management strategy that targeted the valuable predictors for EFF should be incorporated with previous known risk factors to avoid the EFF.

\section{Financial Support}

This research received no specific grant from any funding agency, commercial or not-for-profit sectors.

\section{Conflict of interest}

The authors declare that they have no confict of interest.

\section{Data availability}

The data used to support the findings of this study are available from the corresponding author upon request.

\section{References}

1. Cetta, F., et al., Improved early morbidity and mortality after Fontan operation: the Mayo Clinic experience, 1987 to 1992. Journal of the American College of Cardiology, 1996. 28 (2): p. 480-486.

2. Mayer Jr, J.E., et al., Factors associated with marked reduction in mortality for Fontan operations in patients with single ventricle. The Journal of thoracic and cardiovascular surgery, 1992.103 (3): p. 444-452.

3. Knott-Craig, C.J., et al., The modified Fontan operation: an analysis of risk factors for early postoperative death or takedown in 702 consecutive patients from one institution. The Journal of thoracic and cardiovascular surgery, 1995. 109 (6): p. 1237-1243. 
4. Gentles, T.L., et al., Fontan operation in five hundred consecutive patients: factors influencing early and late outcome. The Journal of thoracic and cardiovascular surgery, 1997. 114 (3): p. 376-391.

5. Hosein, R.B., et al., Factors influencing early and late outcome following the Fontan procedure in the current era. The 'Two Commandments'? European journal of cardio-thoracic surgery, 2007.31 (3): p. 344353.

6. Stewart, R.D., et al., Contemporary Fontan operation: association between early outcome and type of cavopulmonary connection. The Annals of thoracic surgery, 2012. 93 (4): p. 1254-1261.

7. Tweddell, J.S., et al., Fontan palliation in the modern era: factors impacting mortality and morbidity. The Annals of thoracic surgery, 2009. 88 (4): p. 1291-1299.

8. Hirsch, J.C., et al., Fontan operation in the current era: a 15-year single institution experience. Annals of surgery, 2008.248 (3): p. 402-410.

9. Hirsch, J., et al., The lateral tunnel Fontan procedure for hypoplastic left heart syndrome: results of 100 consecutive patients.Pediatric cardiology, 2007. 28 (6): p. 426-432.

10. Hasaniya, N.W., et al., In situ pericardial extracardiac lateral tunnel Fontan operation: fifteen-year experience. The Journal of thoracic and cardiovascular surgery, 2010. 140 (5): p. 1076-1083.

11. Petrossian, E., et al., The extracardiac conduit Fontan operation using minimal approach extracorporeal circulation: early and midterm outcomes. The Journal of thoracic and cardiovascular surgery, 2006. 132 (5): p. 1054-1063.

12. Ovroutski, S., et al., Analysis of the risk factors for early failure after extracardiac Fontan operation. The Annals of thoracic surgery, 2013. 95 (4): p. 1409-1416.

13. O'Brien Jr, J.E., et al., The nonfenestrated extracardiac Fontan procedure: a cohort of 145 patients. The Annals of thoracic surgery, 2010. 89 (6): p. 1815-1820.

14. Iyengar, A.J., et al., The option of taking down the Fontan circulation: the Melbourne experience. Journal of thoracic and cardiovascular surgery (Print), 2010. 139 (5): p. 1346-1348.

15. d'Udekem, Y., et al., The Fontan procedure: contemporary techniques have improved long-term outcomes. Circulation, 2007.116 (11_supplement): p. I-157-I-164.

16. Almond, C.S., et al., Outcome after Fontan failure and takedown to an intermediate palliative circulation. The Annals of thoracic surgery, 2007. 84 (3): p. 880-887.

17. Rogers, L.S., et al., 18 years of the Fontan operation at a single institution: results from 771 consecutive patients. J Am Coll Cardiol, 2012. 60 (11): p. 1018-25.

18. Giannico, S., et al., Clinical outcome of 193 extracardiac Fontan patients: the first 15 years. Journal of the American College of Cardiology, 2006. 47 (10): p. 2065-2073.

19. Meyer, D.B., et al., Outcomes of the Fontan procedure using cardiopulmonary bypass with aortic crossclamping. The Annals of thoracic surgery, 2006. 82 (5): p. 1611-1620.

20. Bautista-Hernandez, V., et al., Right ventricle and tricuspid valve function at midterm after the Fontan operation for hypoplastic left heart syndrome: impact of shunt type. Pediatric cardiology, 2011.32 (2): p. 160-166.

21. Robbers-Visser, D., et al., Results of staged total cavopulmonary connection for functionally univentricular hearts; comparison of intra-atrial lateral tunnel and extracardiac conduit.European journal of cardio-thoracic surgery, 2010. 37 (4): p. 934-941.

22. Rogers, L.S., et al., 18 years of the Fontan operation at a single institution: results from 771 consecutive patients. Journal of the American College of Cardiology, 2012. 60 (11): p. 1018-1025. 
23. Rochelson, E., et al. Identification of risk factors for early Fontan failure . in Seminars in Thoracic and Cardiovascular Surgery . 2020. Elsevier.

24. Murphy, M.O., et al., Management of early Fontan failure: a single-institution experience. European Journal of Cardio-Thoracic Surgery, 2014. 46 (3): p. 458-464.

25. Pundi, K.N., et al., 40-year follow-up after the Fontan operation: long-term outcomes of 1,052 patients. Journal of the American College of Cardiology, 2015. 66 (15): p. 1700-1710.

26. d'Udekem, Y., et al., Predictors of survival after single-ventricle palliation: the impact of right ventricular dominance.Journal of the American College of Cardiology, 2012. 59 (13): p. 1178-1185.

27. Diller, G.-P., et al., Predictors of morbidity and mortality in contemporary Fontan patients: results from a multicenter study including cardiopulmonary exercise testing in 321 patients. European heart journal, 2010. 31 (24): p. 3073-3083.

28. Giglia, T.M. and T. Humpl, Preoperative pulmonary hemodynamics and assessment of operability: is there a pulmonary vascular resistance that precludes cardiac operation? Pediatric Critical Care Medicine, 2010. 11 : p. S57-S69.

29. Chowdhury, U.K., et al., Surgical outcome of staged univentricular-type repairs for patients with univentricular physiology and pulmonary hypertension. Indian Heart Journal, 2004. 56 (4): p. 320-327.

30. Kaza, A.K., et al., Pulmonary vascular remodelling after heart transplantation in patients with cavopulmonary connection. European Journal of Cardio-Thoracic Surgery, 2015. 47 (3): p. 505-510.

31. Ridderbos, F.-J.S., et al., Adverse pulmonary vascular remodeling in the Fontan circulation. The Journal of Heart and Lung Transplantation, 2015. 34 (3): p. 404-413.

32. King, G., et al., Atrioventricular valve failure in Fontan palliation. Journal of the American College of Cardiology, 2019.73 (7): p. 810-822.

33. Schilling, C., et al., The Fontan epidemic: population projections from the Australia and New Zealand Fontan registry.International journal of cardiology, 2016. 219 : p. 14-19.

Table 1. Indications for Fontan surgery

All patients with single ventricular heart undergone bi-directional Glenn operation Age at the operation [?]2 years. No genc

Table 2. Outcomes for patients experiencing early Fontan failure

\begin{tabular}{llllllll}
\hline Patient & Fontan Year & ECMO & Takedown & Transplant & Death & Causes of EFF & Follow-up \\
\hline 1 & 2014 & - & - & - & + & $(1)$ & $\mathrm{n} / \mathrm{a}$ \\
2 & 2014 & - & - & - & + & $(3)$ & $\mathrm{n} / \mathrm{a}$ \\
3 & 2015 & - & - & - & + & $(4)$ & $\mathrm{n} / \mathrm{a}$ \\
4 & 2016 & - & - & - & + & $(2)$ & $\mathrm{n} / \mathrm{a}$ \\
5 & 2016 & - & - & - & + & $(1),(2)$ & $\mathrm{n} / \mathrm{a}$ \\
6 & 2017 & - & - & - & + & $(4)$ & $\mathrm{n} / \mathrm{a}$ \\
7 & 2017 & - & - & - & + & $(1),(2)$ & $\mathrm{n} / \mathrm{a}$ \\
8 & 2017 & - & - & - & + & $(1),(2)$ & $\mathrm{n} / \mathrm{a}$ \\
9 & 2017 & - & - & - & + & $(1)$ & $\mathrm{n} / \mathrm{a}$ \\
10 & 2018 & - & - & - & + & $(1)$ & $\mathrm{n} / \mathrm{a}$ \\
11 & 2018 & - & - & - & + & $(1),(2)$ & $\mathrm{n} / \mathrm{a}$ \\
12 & 2018 & - & - & - & + & $(2),(3)$ & $\mathrm{n} / \mathrm{a}$ \\
13 & 2018 & - & - & - & + & $(2),(5)$ & $\mathrm{n} / \mathrm{a}$
\end{tabular}




\begin{tabular}{llllllll}
\hline Patient & Fontan Year & ECMO & Takedown & Transplant & Death & Causes of EFF & Follow-up \\
\hline 14 & 2019 & - & + & - & - & $(1)$ & Patients survived to the cl \\
\hline
\end{tabular}

ECMO: extracorporeal membrane oxygenation

(1) hemodynamic disorders not responding to treatment; ${ }^{(2)}$ multiorgan dysfunction syndrome; ${ }^{(3)}$ bacterial sepsis or septic shock; ${ }^{(4)}$ cardiac arrest due to arrhythmias; ${ }^{(5)}$ cerebral infarction

Table 3. Association of preoperative data with EFF in entire cohort: Univariate analysis

\begin{tabular}{|c|c|c|c|c|c|c|c|}
\hline Variables & $\begin{array}{l}\text { Fontan } \\
\text { failure ( } \mathrm{n} \\
=14)\end{array}$ & $\begin{array}{l}\text { Fontan } \\
\text { failure ( } \mathrm{n} \\
=14)\end{array}$ & $\begin{array}{l}\text { No } \\
\text { Fontan } \\
\text { failure (n } \\
=131)\end{array}$ & $\begin{array}{l}\text { No } \\
\text { Fontan } \\
\text { failure (n } \\
=131)\end{array}$ & $\begin{array}{l}\text { Univariate } \\
\text { analysis }\end{array}$ & $\begin{array}{l}\text { Univariate } \\
\text { analysis }\end{array}$ & $\begin{array}{l}\text { Univariate } \\
\text { analysis }\end{array}$ \\
\hline & Count & $\begin{array}{l}\% \text { of } \\
\text { total }\end{array}$ & Count & $\begin{array}{l}\% \text { of } \\
\text { total }\end{array}$ & OR & $95 \% \mathrm{CI}$ & $\mathrm{p}$ value \\
\hline \multicolumn{8}{|l|}{ Gender } \\
\hline Male & 6 & 42.86 & 79 & 60.31 & 1 & - & \\
\hline Female & 8 & 57.14 & 52 & 39.7 & 2.03 & $0.66-6.18$ & 0.215 \\
\hline $\begin{array}{l}\text { Diaphragm } \\
\text { paralysis }\end{array}$ & 0 & 0.00 & 1 & 0.76 & - & - & \\
\hline $\begin{array}{l}\text { Prolonged } \\
\text { pleural } \\
\text { effusion }\end{array}$ & 0 & 0.00 & 3 & 2.29 & - & - & \\
\hline Chylothorax & 0 & 0.00 & 1 & 0.76 & - & - & \\
\hline Pleurodesis & 0 & 0.00 & 1 & 0.76 & - & - & \\
\hline $\begin{array}{l}\text { Neurological } \\
\text { complications } \\
\text { Heart } \\
\text { failure * }\end{array}$ & 0 & 0.00 & 3 & 2.29 & - & - & \\
\hline II grade & 6 & 42.86 & 67 & 51.15 & 1 & - & \\
\hline $\begin{array}{l}\text { III grade } \\
\text { ECG } \\
\text { results }\end{array}$ & 8 & 57.14 & 64 & 48.85 & 1.40 & $0.46-4.25$ & 0.557 \\
\hline $\begin{array}{l}\text { Sinus } \\
\text { rhythm }\end{array}$ & 14 & 100.00 & 120 & 91.60 & - & - & \\
\hline $\begin{array}{l}\text { Atrial } \\
\text { rhythm }\end{array}$ & 0 & 0.00 & 5 & 3.82 & - & - & \\
\hline $\begin{array}{l}\text { Junctional } \\
\text { rhythm } \\
\text { Anatomical } \\
\text { diagnosis } \\
\text { of single- } \\
\text { ventricle } \\
\text { lesions }\end{array}$ & 0 & 0.00 & 6 & 4.58 & - & - & \\
\hline $\begin{array}{l}\text { Tricuspid } \\
\text { atresia }\end{array}$ & 1 & 7.14 & 23 & 17.56 & 0.36 & $0.04-2.90$ & 0.338 \\
\hline $\begin{array}{l}\text { Mitral } \\
\text { atresia/ } \\
\text { hypoplastic } \\
\text { mitral valve }\end{array}$ & 0 & 0.00 & 10 & 7.63 & - & - & \\
\hline
\end{tabular}




\begin{tabular}{|c|c|c|c|c|c|c|c|}
\hline Variables & $\begin{array}{l}\text { Fontan } \\
\text { failure (n } \\
=14)\end{array}$ & $\begin{array}{l}\text { Fontan } \\
\text { failure (n } \\
=14)\end{array}$ & $\begin{array}{l}\text { No } \\
\text { Fontan } \\
\text { failure (n } \\
=131)\end{array}$ & $\begin{array}{l}\text { No } \\
\text { Fontan } \\
\text { failure (n } \\
=131)\end{array}$ & $\begin{array}{l}\text { Univariate } \\
\text { analysis }\end{array}$ & $\begin{array}{l}\text { Univariate } \\
\text { analysis }\end{array}$ & $\begin{array}{l}\text { Univariate } \\
\text { analysis }\end{array}$ \\
\hline $\begin{array}{l}\text { Double inlet } \\
\text { single } \\
\text { ventricle }\end{array}$ & 1 & 7.14 & 20 & 15.27 & 0.43 & $0.05-3.45$ & 0.425 \\
\hline $\begin{array}{l}\text { Ebstein } \\
\text { anomaly }\end{array}$ & 1 & 7.14 & 3 & 2.29 & 3.28 & $0.32-33.87$ & 0.318 \\
\hline PA with IVS & 0 & 0.00 & 3 & 2.29 & - & - & \\
\hline $\begin{array}{l}\text { Corrected } \\
\text { congenital } \\
\text { TGA }\end{array}$ & 1 & 7.14 & 9 & 6.87 & 1.04 & $0.12-8.89$ & 0.969 \\
\hline $\begin{array}{l}\text { DORV with } \\
\text { TGA }\end{array}$ & 2 & 14.29 & 41 & 31.30 & 0.37 & $0.08-1.71$ & 0.201 \\
\hline $\begin{array}{l}\text { Unbalanced } \\
\text { AV septal } \\
\text { defect }\end{array}$ & 6 & 42.86 & 16 & 12.21 & 5.39 & $\begin{array}{l}1.66- \\
17.55\end{array}$ & 0.005 \\
\hline $\begin{array}{l}\text { AV septal } \\
\text { defect with } \\
\text { TGA } \\
\text { Viscero- } \\
\text { atrial } \\
\text { situs }\end{array}$ & 2 & 14.29 & 6 & 4.58 & 3.47 & $0.63-19.13$ & 0.153 \\
\hline Situs solitus & 8 & 57.14 & 100 & 76.34 & 1 & - & \\
\hline $\begin{array}{l}\text { Situs } \\
\text { inversus }\end{array}$ & 5 & 35.71 & 17 & 12.98 & 3.68 & $\begin{array}{l}1.07- \\
12.58\end{array}$ & 0.038 \\
\hline $\begin{array}{l}\text { Situs } \\
\text { ambiguus } \\
\text { Systemic } \\
\text { ventricu- } \\
\text { lar } \\
\text { morphology }\end{array}$ & 1 & 7.14 & 14 & 10.69 & 0.89 & $0.10-7.69$ & 0.918 \\
\hline $\begin{array}{l}\text { Right } \\
\text { ventricle }\end{array}$ & 7 & 50.00 & 28 & 21.37 & 1 & - & \\
\hline $\begin{array}{l}\text { Left } \\
\text { ventricle }\end{array}$ & 2 & 14.29 & 33 & 25.19 & 0.24 & $0.05-1.26$ & 0.092 \\
\hline $\begin{array}{l}\text { Two- } \\
\text { ventricle }\end{array}$ & 5 & 35.71 & 53 & 40.46 & 0.38 & $0.11-1.30$ & 0.122 \\
\hline $\begin{array}{l}\text { Unidentified } \\
\text { Number of } \\
\text { AV valve }\end{array}$ & 0 & 0.00 & 17 & 12.98 & - & - & \\
\hline One valve & 10 & 71.43 & 59 & 45.04 & 1 & - & \\
\hline $\begin{array}{l}\text { Two valves } \\
\text { Atrioventricul } \\
\text { valve } \\
\text { regurgitation }\end{array}$ & 4 & 28.57 & 72 & 54.96 & 0.33 & $0.10-1.10$ & 0.071 \\
\hline Mild & 6 & 42.86 & 73 & 55.73 & 1 & - & \\
\hline Moderate & 8 & 57.14 & 21 & 16.03 & 4.63 & $\begin{array}{l}1.45- \\
14.85\end{array}$ & 0.01 \\
\hline No & 0 & 0.00 & 37 & 28.24 & - & - & \\
\hline
\end{tabular}




\begin{tabular}{|c|c|c|c|c|c|c|c|}
\hline Variables & $\begin{array}{l}\text { Fontan } \\
\text { failure }(\mathrm{n} \\
=14)\end{array}$ & $\begin{array}{l}\text { Fontan } \\
\text { failure ( } \mathrm{n} \\
=14)\end{array}$ & $\begin{array}{l}\text { No } \\
\text { Fontan } \\
\text { failure (n } \\
=131)\end{array}$ & $\begin{array}{l}\text { No } \\
\text { Fontan } \\
\text { failure (n } \\
=131)\end{array}$ & $\begin{array}{l}\text { Univariate } \\
\text { analysis }\end{array}$ & $\begin{array}{l}\text { Univariate } \\
\text { analysis }\end{array}$ & $\begin{array}{l}\text { Univariate } \\
\text { analysis }\end{array}$ \\
\hline \multicolumn{8}{|c|}{$\begin{array}{l}\text { Atrioventricular } \\
\text { valve } \\
\text { status }\end{array}$} \\
\hline $\begin{array}{l}\text { Normal } \\
\text { valve }\end{array}$ & 14 & 100.00 & 127 & 96.95 & - & - & \\
\hline $\begin{array}{l}\text { Mechanical } \\
\text { artificial } \\
\text { valve }\end{array}$ & 0 & 0.00 & 1 & 0.76 & - & - & \\
\hline $\begin{array}{l}\text { Biological } \\
\text { artificial } \\
\text { valve }\end{array}$ & 0 & 0.00 & 3 & 2.29 & - & - & \\
\hline $\begin{array}{l}\text { Systemic } \\
\text { ventricu- } \\
\text { lar outflow } \\
\text { obstruction }\end{array}$ & 0 & 0.00 & 8 & 6.11 & - & - & \\
\hline $\begin{array}{l}\text { Subaortic } \\
\text { stenosis }\end{array}$ & 0 & 0.00 & 5 & 3.82 & - & - & \\
\hline $\begin{array}{l}\text { Restricted } \\
\text { VSD }\end{array}$ & 0 & 0.00 & 3 & 2.29 & - & - & \\
\hline \multicolumn{2}{|c|}{$\begin{array}{l}\text { Cavopulmonary1 } \\
\text { anastomo- } \\
\text { sis } \\
\text { stenosis }\end{array}$} & 7.14 & 0 & 0.00 & - & - & \\
\hline $\begin{array}{l}\text { Pulmonary } \\
\text { artery } \\
\text { distortion }\end{array}$ & 0 & 0.00 & 1 & 0.76 & - & - & \\
\hline $\begin{array}{l}\text { Patent } \\
\text { arterial } \\
\text { duct }\end{array}$ & 0 & 0.00 & 2 & 1.53 & - & - & \\
\hline $\begin{array}{l}\text { Large } \\
\text { aorta- } \\
\text { pulmonary } \\
\text { circulation } \\
\text { in Doppler } \\
\text { echocardiog }\end{array}$ & 5 & 35.71 & 10 & 7.63 & 6.72 & $\begin{array}{l}1.89- \\
23.92\end{array}$ & 0.003 \\
\hline $\begin{array}{l}\text { Ventricle- } \\
\text { to- } \\
\text { pulmonary } \\
\text { artery } \\
\text { shunt }\end{array}$ & 4 & 28.57 & 46 & 35.11 & 0.74 & $0.22-2.49$ & 0.625 \\
\hline \multirow[t]{2}{*}{$\begin{array}{l}\text { Large } \\
\text { aorta- } \\
\text { pulmonary } \\
\text { circulation } \\
\text { in cardiac } \\
\text { catheterizatio }\end{array}$} & 7 & 50.00 & 43 & 32.82 & 2.05 & $0.67-6.21$ & 0.206 \\
\hline & Mean $\pm S D$ & Range & Mean $\pm S D$ & Range & OR & $95 \% \mathrm{CI}$ & $\mathrm{p}$ value \\
\hline
\end{tabular}




\begin{tabular}{|c|c|c|c|c|c|c|c|}
\hline Variables & $\begin{array}{l}\text { Fontan } \\
\text { failure }(\mathrm{n} \\
=14)\end{array}$ & $\begin{array}{l}\text { Fontan } \\
\text { failure }(\mathrm{n} \\
=14)\end{array}$ & $\begin{array}{l}\text { No } \\
\text { Fontan } \\
\text { failure }(\mathrm{n} \\
=131)\end{array}$ & $\begin{array}{l}\text { No } \\
\text { Fontan } \\
\text { failure (n } \\
=131)\end{array}$ & $\begin{array}{l}\text { Univariate } \\
\text { analysis }\end{array}$ & $\begin{array}{l}\text { Univariate } \\
\text { analysis }\end{array}$ & $\begin{array}{l}\text { Univariate } \\
\text { analysis }\end{array}$ \\
\hline $\begin{array}{l}\text { Age } \\
\text { (months) }\end{array}$ & $67.71 \pm 63.71$ & $28-240$ & $68.11 \pm 53.15$ & $24-426.7$ & 1.00 & $0.99-1.01$ & 0.979 \\
\hline $\begin{array}{l}\text { Height } \\
(\mathrm{cm})\end{array}$ & $95 \pm 33.88$ & $10-155$ & $103.4 \pm 18.0$ & $80-165$ & 0.98 & $0.95-1.01$ & 0.137 \\
\hline $\begin{array}{l}\text { Weight } \\
(\mathrm{kg})\end{array}$ & $17.2 \pm 12.0$ & $9-51$ & $16.4 \pm 7.7$ & $8.5-49.5$ & 1.01 & $0.95-1.08$ & 0.726 \\
\hline $\begin{array}{l}\text { PAP in } \\
\text { cardiac } \\
\text { catheteri- } \\
\text { zation } \\
(\mathrm{mmHg}) \\
(\mathrm{n}=142)\end{array}$ & $12.86 \pm 1.66$ & $11-16$ & $11.26 \pm 2.16$ & $7-17$ & 1.40 & $\begin{array}{l}1.08- \\
1.82\end{array}$ & 0.011 \\
\hline $\begin{array}{l}\text { VEDP } \\
(\mathrm{mmHg}) \\
(\mathrm{n}=129)\end{array}$ & $4.85 \pm 1.34$ & $2-6$ & $5.07 \pm 1.65$ & $2-12$ & 0.92 & $0.62-1.33$ & 0.637 \\
\hline $\begin{array}{l}\text { PAI }(\mathrm{n}= \\
137)\end{array}$ & $336.93 \pm 230.66$ & $170-1037$ & $322.6 \pm 100.23$ & $140-676$ & 1.00 & $0.99-1.01$ & 0.669 \\
\hline $\begin{array}{l}\mathrm{Rp} \\
\left(\operatorname{wood} / \mathrm{m}^{2}\right) \\
(\mathrm{n}=64)\end{array}$ & $2.66 \pm 0.55$ & $1.6-3.7$ & $1.79 \pm 0.77$ & $0.3-3.3$ & 6.73 & $\begin{array}{l}1.65- \\
27.39\end{array}$ & 0.008 \\
\hline
\end{tabular}

*NYHA Heart Failure Classification; EFF: early Fontan failure; ECG: Electrocardiography; DORV: double outlet right ventricle; TGA: transposition of great arteries; PA: pulmonary atresia; IVS: intact ventricular septum; AV: atrioventricular; PAP: pulmonary artery pressure; VEDP: ventricular end-diastolic pressure; PAI: pulmonary artery index; Rp: Pulmonary vascular resistance; OR: odd ratio; 95\%CI: 95\% confidence interval

Table 4. Association of operative and postoperative data with EFF in entire cohort: Univariate analysis

\begin{tabular}{|c|c|c|c|c|c|c|c|}
\hline Variables & $\begin{array}{l}\text { Fontan } \\
\text { failure (n } \\
=14)\end{array}$ & $\begin{array}{l}\text { Fontan } \\
\text { failure (n } \\
=14)\end{array}$ & $\begin{array}{l}\text { No } \\
\text { Fontan } \\
\text { failure (n } \\
=131)\end{array}$ & $\begin{array}{l}\text { No } \\
\text { Fontan } \\
\text { failure (n } \\
=131)\end{array}$ & $\begin{array}{l}\text { Univariate } \\
\text { analysis }\end{array}$ & $\begin{array}{l}\text { Univariate } \\
\text { analysis }\end{array}$ & $\begin{array}{l}\text { Univariate } \\
\text { analysis }\end{array}$ \\
\hline & Count & $\begin{array}{l}\% \text { of } \\
\text { total }\end{array}$ & Count & $\begin{array}{l}\% \text { of } \\
\text { total }\end{array}$ & OR & $95 \%$ CI & p value \\
\hline
\end{tabular}

At

Fontan

Pulmonary 4

artery

$28.57 \quad 11$

8.4

4.36

$1.17-$

16.23

0.028

reconstruction

DKS 1

$1 \quad 7.14$

3

2.29

3.28

$0.32-$

procedure

3

21.43

1

0.76

35.45

33.87

repair

-

(1)

$3.40-$

370.04 


\begin{tabular}{|c|c|c|c|c|c|c|c|}
\hline Variables & $\begin{array}{l}\text { Fontan } \\
\text { failure ( } \mathrm{n} \\
=14)\end{array}$ & $\begin{array}{l}\text { Fontan } \\
\text { failure ( } \mathrm{n} \\
=14)\end{array}$ & $\begin{array}{l}\text { No } \\
\text { Fontan } \\
\text { failure (n } \\
=131)\end{array}$ & $\begin{array}{l}\text { No } \\
\text { Fontan } \\
\text { failure (n } \\
=131)\end{array}$ & $\begin{array}{l}\text { Univariate } \\
\text { analysis }\end{array}$ & $\begin{array}{l}\text { Univariate } \\
\text { analysis }\end{array}$ & $\begin{array}{l}\text { Univariate } \\
\text { analysis }\end{array}$ \\
\hline $\begin{array}{l}\text { Replacement } \\
\text { of AV } \\
\text { valve }\end{array}$ & 0 & 0.00 & 1 & 0.76 & - & - & \\
\hline $\begin{array}{l}\text { Atrial sep- } \\
\text { tostomy } \\
\text { procedure }\end{array}$ & 0 & 0.00 & 16 & 12.21 & - & - & \\
\hline $\begin{array}{l}\text { Dissection } \\
\text { APCA }\end{array}$ & 0 & 0.00 & 1 & 0.76 & - & - & \\
\hline $\begin{array}{l}\text { Ligation } \\
\text { APCA } \\
\text { Fontan } \\
\text { tube } \\
\text { grafts }\end{array}$ & 0 & 0.00 & 1 & 0.76 & - & - & \\
\hline Gortex & 4 & 28.57 & 66 & 50.38 & 1 & - & \\
\hline Unigraff & 10 & 71.43 & 65 & 49.62 & 2.54 & $0.76-8.50$ & 0.131 \\
\hline $\begin{array}{l}\text { Aortic } \\
\text { cross- } \\
\text { clamping }\end{array}$ & 14 & 100.00 & 112 & 85.50 & - & - & \\
\hline Bleeding & 4 & 28.57 & 3 & 2.29 & 17.07 & $\begin{array}{l}3.35- \\
87.06\end{array}$ & 0.001 \\
\hline \multicolumn{8}{|l|}{$\begin{array}{l}\text { At post- } \\
\text { Fontan }\end{array}$} \\
\hline Edema & 4 & 28.57 & 5 & 3.28 & 10.08 & $\begin{array}{l}2.33- \\
43.58\end{array}$ & 0.002 \\
\hline $\begin{array}{l}\text { Effusion } \\
>14 \text { days }\end{array}$ & 0 & 0.00 & 29 & 22.14 & - & - & \\
\hline $\begin{array}{l}\text { At } \\
\text { Fontan }\end{array}$ & Mean $\pm S D$ & Range & Mean士SD & Range & OR & $95 \% \mathrm{CI}$ & p value \\
\hline $\begin{array}{l}\text { Aortic } \\
\text { cross- } \\
\text { clamping } \\
\text { time } \\
\text { (mins) }\end{array}$ & $50.29 \pm 18.03$ & $17-76$ & $48.69 \pm 24.75$ & $3-168$ & 1.00 & $0.98-1.03$ & 0.814 \\
\hline $\begin{array}{l}\text { Cardiopulmon } \\
\text { bypass } \\
\text { time } \\
\text { (mins) }\end{array}$ & $\operatorname{args} 5.36 \pm 17.47$ & $60-121$ & $82.64 \pm 30.42$ & $30-258$ & 1.00 & $0.99-1.02$ & 0.742 \\
\hline $\begin{array}{l}\text { Total } \\
\text { support } \\
\text { time } \\
\text { (mins) }\end{array}$ & $15.64 \pm 5.73$ & $10-30$ & $19.85 \pm 14.17$ & $6-84$ & 0.97 & $0.91-1.03$ & 0.276 \\
\hline $\begin{array}{l}\text { PAP } \\
(\mathrm{mmHg}) \\
\text { At post- } \\
\text { Fontan }\end{array}$ & $17.41 \pm 3.02$ & $14-23$ & $14.85 \pm 3.43$ & $7-25$ & 1.23 & $\begin{array}{l}1.07- \\
1.48\end{array}$ & 0.005 \\
\hline
\end{tabular}




\begin{tabular}{|c|c|c|c|c|c|c|c|}
\hline Variables & $\begin{array}{l}\text { Fontan } \\
\text { failure }(\mathrm{n} \\
=14)\end{array}$ & $\begin{array}{l}\text { Fontan } \\
\text { failure (n } \\
=14)\end{array}$ & $\begin{array}{l}\text { No } \\
\text { Fontan } \\
\text { failure (n } \\
=131)\end{array}$ & $\begin{array}{l}\text { No } \\
\text { Fontan } \\
\text { failure (n } \\
=131)\end{array}$ & $\begin{array}{l}\text { Univariate } \\
\text { analysis }\end{array}$ & $\begin{array}{l}\text { Univariate } \\
\text { analysis }\end{array}$ & $\begin{array}{l}\text { Univariate } \\
\text { analysis }\end{array}$ \\
\hline $\begin{array}{l}\text { PAP } \\
(\mathrm{mmHg})\end{array}$ & $20.29 \pm 5.48$ & $13-31$ & $15.8 \pm 9.58$ & $8-118$ & 1.03 & $0.99-1.07$ & 0.177 \\
\hline
\end{tabular}

DKS: Damus-Kaye-Stansel; AV: atrioventricular; APCA: aortopulmonary collateral arteries; PAP: pulmonary artery pressure; OR: odd ratio; 95\%CI: 95\% confidence interval

Table 5. A reduced model including the predictors for EFF in entire cohort: multivariate logistic regression analysis

\begin{tabular}{|c|c|c|c|}
\hline Variables & $\begin{array}{l}\text { Multivariate logistic } \\
\text { regression }\end{array}$ & $\begin{array}{l}\text { Multivariate logistic } \\
\text { regression }\end{array}$ & $\begin{array}{l}\text { Multivariate logistic } \\
\text { regression }\end{array}$ \\
\hline & OR & $95 \% \mathrm{CI}$ & $p$ value \\
\hline \multicolumn{4}{|l|}{ At pre-Fontan } \\
\hline Age & 1.06 & $0.99-1.12$ & 0.069 \\
\hline Height & 0.89 & $0.76-1.04$ & 0.153 \\
\hline $\begin{array}{l}\text { Large aorta-pulmonary } \\
\text { circulation in Doppler } \\
\text { echocardiography (vs } \\
\text { no) }\end{array}$ & 1 & - & \\
\hline Yes & 12.45 & $0.58-257.60$ & 0.107 \\
\hline $\begin{array}{l}\text { PAP in cardiac } \\
\text { catheterization }\end{array}$ & 1.84 & $1.12-3.00$ & 0.016 \\
\hline \multicolumn{4}{|l|}{ At Fontan } \\
\hline $\begin{array}{l}\text { Repair of AV valve at } \\
\text { Fontan (vs no) }\end{array}$ & 1 & - & \\
\hline Yes & 65.85 & $1.95-2228.14$ & 0.020 \\
\hline Bleeding (vs no) & 1 & - & \\
\hline Yes & 8.50 & $0.40-178.76$ & 0.168 \\
\hline \multicolumn{4}{|l|}{ At post-Fontan } \\
\hline PAP & 1.66 & $1.19-2.33$ & 0.004 \\
\hline
\end{tabular}

PAP: pulmonary artery pressure; OR: odd ratio; 95\%CI: 95\% confidence interval

Table 6. Series of Fontan procedures where survival after early Fontan failure was reported

\begin{tabular}{|c|c|c|c|c|c|c|c|c|}
\hline & Era & Patients & $\begin{array}{l}\text { EFF } \\
\text { incidence } \\
(\%)\end{array}$ & $\begin{array}{l}\text { EFF } \\
\text { survival } \\
(\%)\end{array}$ & $\begin{array}{l}\text { Death } \\
(\%)\end{array}$ & $\begin{array}{l}\text { Takedown } \\
(\%)\end{array}$ & $\begin{array}{l}\text { ECMO } \\
(\%)\end{array}$ & OHT \\
\hline $\begin{array}{l}\text { Current } \\
\text { series }\end{array}$ & $2012-19$ & 145 & 9.7 & 7.1 & 8.9 & 0.7 & 0.0 & 0.0 \\
\hline $\begin{array}{l}\text { Murphy } \\
{[24]}\end{array}$ & $\begin{array}{l}1995- \\
2009\end{array}$ & 592 & 1.9 & 54 & 0.8 & 0.8 & 0.8 & 0.3 \\
\hline $\begin{array}{l}\text { Ovroutski } \\
{[12]}\end{array}$ & $\begin{array}{l}1995^{-} \\
2011\end{array}$ & 140 & 7.1 & 10 & 6.4 & 0.7 & 3.5 & 0.0 \\
\hline
\end{tabular}




\begin{tabular}{|c|c|c|c|c|c|c|c|c|}
\hline & Era & Patients & $\begin{array}{l}\text { EFF } \\
\text { incidence } \\
(\%)\end{array}$ & $\begin{array}{l}\text { EFF } \\
\text { survival } \\
(\%)\end{array}$ & $\begin{array}{l}\text { Death } \\
(\%)\end{array}$ & $\begin{array}{l}\text { Takedown } \\
(\%)\end{array}$ & $\begin{array}{l}\text { ECMO } \\
(\%)\end{array}$ & OHT \\
\hline Hirsh [8] & $\begin{array}{l}1992- \\
2007\end{array}$ & 636 & 4.2 & 37 & 3.0 & 3.0 & 2.0 & 0.0 \\
\hline $\begin{array}{l}\text { Meyer } \\
{[19]}\end{array}$ & 2000-04 & 160 & 1.8 & 33 & 1.3 & 1.3 & 1.9 & 0.0 \\
\hline $\begin{array}{l}\text { Bautista- } \\
\text { Hernandez } \\
{[20]}\end{array}$ & $2000-07$ & 118 & 2.5 & 66 & 0.8 & 0.0 & 2.5 & 0.0 \\
\hline $\begin{array}{l}\text { Robbers- } \\
\text { Visser } \\
{[21]}\end{array}$ & $\begin{array}{l}1988- \\
2008\end{array}$ & 209 & 4.3 & 0 & 4.0 & 0.0 & 0.5 & 0.0 \\
\hline $\begin{array}{l}\text { O'Brien } \\
\text { [13] }\end{array}$ & $\begin{array}{l}1997- \\
2008\end{array}$ & 145 & 6.2 & 11 & 5.5 & 2.8 & 0.0 & 0.0 \\
\hline $\begin{array}{l}\text { Petrossian } \\
{[11]}\end{array}$ & $\begin{array}{l}1992- \\
2005\end{array}$ & 285 & 2.5 & 57 & 1.1 & 1.4 & 0.0 & 0.0 \\
\hline $\begin{array}{l}\text { Hasaniya } \\
{[10]}\end{array}$ & $\begin{array}{l}1994- \\
2009\end{array}$ & 160 & 2.0 & 33 & 1.3 & 0.7 & 0.0 & 0.0 \\
\hline $\begin{array}{l}\text { Hosein } \\
{[5]}\end{array}$ & $\begin{array}{l}1988- \\
2004\end{array}$ & 406 & 5.4 & 18 & 4.4 & 2.2 & 0.0 & 0.0 \\
\hline $\begin{array}{l}\text { Giannico } \\
{[18]}\end{array}$ & $\begin{array}{l}1988^{-} \\
2003\end{array}$ & 221 & 12.7 & 21 & 9.9 & 5.4 & 0.0 & 0.0 \\
\hline $\begin{array}{l}\text { D'Udekem } \\
{[15]}\end{array}$ & $\begin{array}{l}1980- \\
2000\end{array}$ & 305 & 4.9 & 33 & 3.0 & 2.3 & 0.0 & 0.0 \\
\hline $\begin{array}{l}\text { Azakie } \\
{[25]}\end{array}$ & 1994-98 & 107 & 7.5 & 25 & 5.6 & 3.7 & 0.0 & 0.0 \\
\hline $\begin{array}{l}\text { Gentles } \\
{[4]}\end{array}$ & 1973-91 & 500 & 16.8 & 12 & 14.8 & 6.0 & 0.0 & 0.0 \\
\hline $\begin{array}{l}\text { Knott- } \\
\text { Craig } \\
{[3]}\end{array}$ & 1973-89 & 702 & 14.8 & 6 & 14.0 & 2.3 & 0.0 & 0.0 \\
\hline
\end{tabular}

EFF: early Fontan failure; ECMO: extracorporeal membrane oxygenation; OHT: orthotropic heart transplant 